\title{
The Concept of Region Tourism Management
}

\author{
Anastasiya N. Rusina 1*[ORCID 0000-0002-1477-2840], \\ Ekaterina A. Yakimova 1[ORCID 0000-0001-8895-2708], \\ Olga V. Karpycheva 1[ORCID 0000-0002-2050-9635]
}

\author{
${ }^{1}$ Siberian Federal University, Krasnoyarsk, Russia \\ kozitsina55@mail.ru
}

\begin{abstract}
The paper considers topical issues of the development of domestic tourism management systems. The purpose of the article is to develop a management concept for the tourism industry, which allows for a comprehensive analysis of the current state and development potential of the tourism industry and formulate management decisions for the development of the tourism industry in the region. The authors use methods of statistical data analysis, structural analysis and quantitative assessment of criteria. The article develops the concept of management of the tourism industry at the regional level, developed an algorithm for identifying "zones of attraction" in the region, a functional diagram of monitoring, control and adjustment of management decisions. On the basis of statistical data and a quantitative assessment of the criteria in the context of municipalities, the zones of attraction of the region's territory are determined. Based on the indicators of the implementation of the tourist potential and the level of development of tourism infrastructure, a positioning map of the municipalities of the region is built, on the basis of which management decisions are developed. The results of approbation of the concept made it possible, using the example of the Krasnoyarsk Territory, to demonstrate the system of identifying the current and potential "zones of attraction" of the region in the context of municipalities, which makes it possible to form management decisions in the development of the tourism industry of the territories. Thus, the use of the developed management methodology for the tourism industry will allow us to determine the point places of attraction of tourists and to work out in more detail possible management decisions, which will increase the level of tourist attractiveness of the region as a whole. The results obtained represent the basis for the application of the developed toolkit by the subjects of state and municipal management of the regions of Russia in order to make scientifically grounded management decisions in the development of tourism products in the region as part of the implementation of the tourism development strategy.
\end{abstract}

Keywords: tourism, domestic tourism, zones of attraction, tourist potential, attractiveness of the territory, management concept

\section{INTRODUCTION}

In Russia, tourism is an important area of economic development both for the entire country as a whole and for individual regions. However, unlike a number of foreign countries, the direction of domestic tourism is underdeveloped in our country, which is mostly due to the low level of development of tourism infrastructure, the discrepancy between the price and quality of tourist services, low level of service, and a lack of qualified personnel.

According to the "Strategy for the development of tourism in the Russian Federation for the period up to 2035 ", the main course of the industry is aimed at the development of domestic and inbound tourism in Russia through the formation of a competitive tourist product, infrastructure development, provision of high-quality and affordable tourist services on the territory of the Russian Federation, focusing on the best domestic and international experience in the development of tourist clusters and attracting potential customers to places of attraction [1].

Currently, the issue of the development of domestic tourism is becoming more and more relevant due to the impact of a number of external 
factors: the unstable political situation in a number of countries, a ban on the entry/exit of Russian tourists to some popular foreign resorts, coronavirus restrictions, etc.

Such constraints should be considered as an additional opportunity for the development of domestic tourism, which will allow, firstly, to reduce losses from international tourism, and secondly, to increase interest in domestic destinations, including within the regions. However, the development of the industry requires not only the development and improvement of a competitive tourist product, the development of tourism infrastructure, the provision of high-quality and affordable tourist services in the regions of the country, but also the formation of a clear management system for the industry.

The development of domestic tourism is reflected in the works of N.K. Serdyukova, D.A. Tsygankov, V.P. Silina, L.A. Bragin, T.A. Lavrova, O. Makara, V. Maiboroda, L. Andrades, I. Arbulu, S. Khalil, A. Ragab, A. Ghorbani, B. Bayih [2-10] and others. The works consider the methods of forecasting the demand for sustainable tourism development [11-13] based on econometric principles and modeling. N. Doğanalp and A. Arslan [14] propose a methodology for assessing the effectiveness of the tourism industry based on the analysis of data coverage (calculation of indices: natural, socio-cultural and substructure). S. Ahmeti, A. Demi, M. Katsioloudes consider the development of the tourism sector based on the generalization of the theory of consumer behavior [15]. However, in the literature, the issue of developing a generalized management system for the tourism industry, including at the regional level, has not been sufficiently worked out.

Thus, the purpose of the article is to develop a management concept for the tourism industry, which allows for a comprehensive analysis of the current state and development potential of the tourism sector and formulate management decisions for the development of the tourism industry in the region.

\section{MATERIALS AND METHODS}

To achieve this goal, the authors have developed conceptual stages of management of the tourism industry in the region, an algorithm for identifying "zones of attraction" in the region, a functional diagram of monitoring, control and adjustment of management decisions.

The following methods served as the methodological basis of the research:
- content analysis of scientific publications on the research topic made it possible to identify the main trends and problems of market development;

- structural analysis and quantitative assessment of the criteria for the proposed indicators, allowing to identify the state of the tourism industry in the region, to highlight the "zones of attraction" of the territory.

The initial data of the study were secondary data, including statistical data on the development of municipalities in the Krasnoyarsk Territory [16-18].

\section{RESULTS}

The conceptual scheme of management of the tourism industry includes three stages (Figure 1).

Stage 1. Calculation of criteria indicators for the analysis of the tourism industry in the region;

Stage 2. Allocation of "zones of attraction" based on the criteria indicators identified at the first stage;

Stage 3. Formation of management decisions.

The algorithm for identifying "zones of attraction" is based on characteristics, the intersection of which will clearly identify zones of active tourism development or potential zones for attracting tourists.

Attraction zones characteristics:

- spatial location - the boundary of the location of the municipal formation (hereinafter municipalities) of the region, on the territory of which the zones of attraction are located;

- the level of realization of the tourism potential - the zone belongs to a municipal entity that brings the greatest contribution from the tourism industry to the economy of the region;

- infrastructural component - the level of development of tourism infrastructure in the region's municipalities (the number of tourist facilities, the number of catering establishments, the number of collective accommodations).

The intersection of these characteristics will make it possible to identify the "zones of attraction" of tourists on the territory of the region, taking into account the connectivity according to the criteria of spatial location, the level of realization of the tourist potential and the level of development of the tourism infrastructure. 


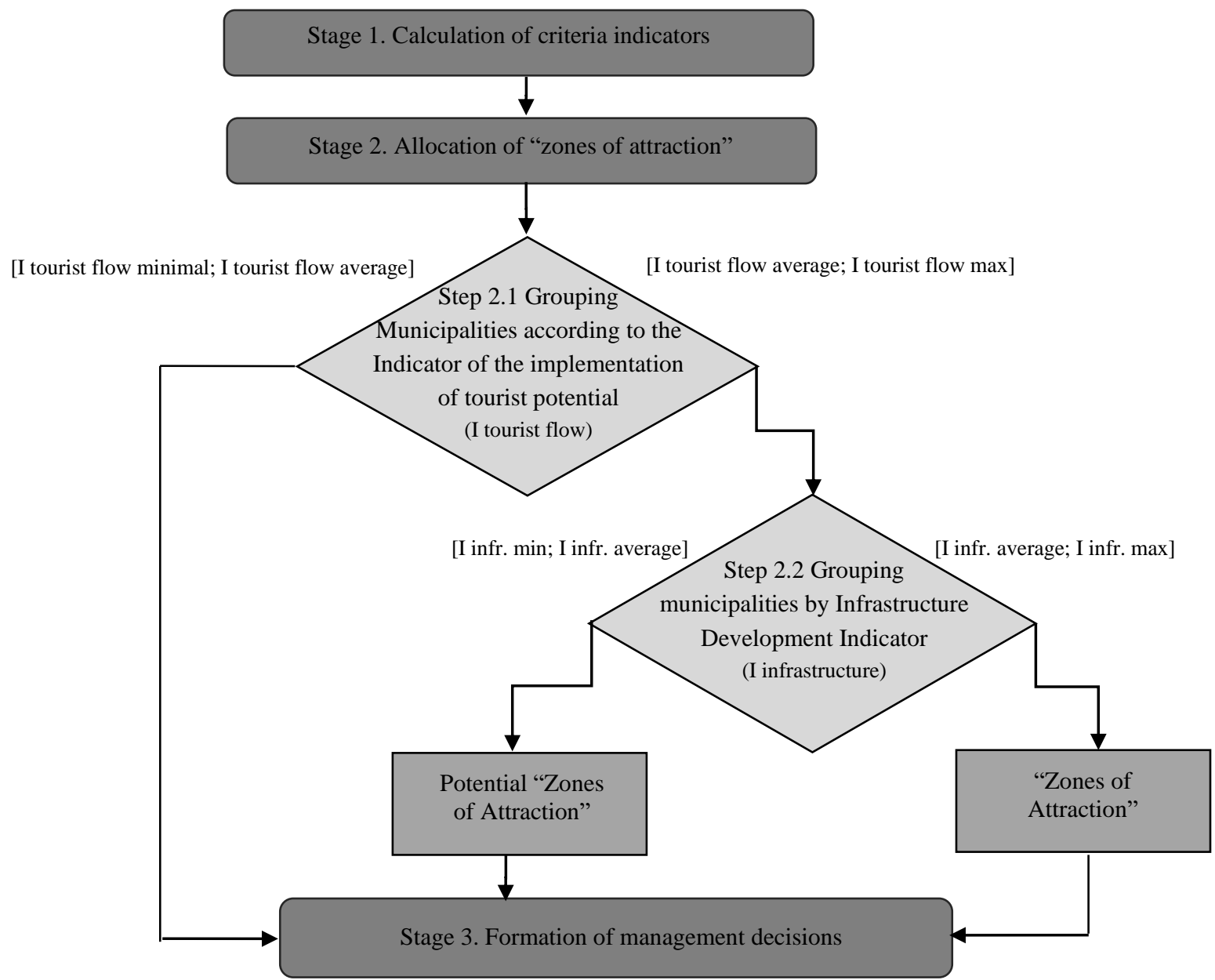

Figure 1. Conceptual scheme of management of the tourism industry in the region Source: Compiled by the authors

Criteria for identifying zones of attraction:

- turnover of organizations by economic activity in the field of Tourism in the municipalities, thousand rubles;

- turnover of organizations by economic activity in all industries in the municipalities;

- the number of collective accommodation facilities (room supply) in the municipalities;

- the number of population employed in tourism in the municipalities;

- the number of catering establishments (number of seats) in the municipalities;

- the number of tourists in the municipal district, people population of the municipal district, people.

As a result of correlating these criteria, territorial zones are distinguished, the most attractive places for recreation in the region. The calculation of the quantitative indicators proposed by the authors for the allocation of "zones of attraction" in the region is carried out for each municipal entity that is part of the administrative-territorial composition of the region, in accordance with the methods described in Table 1.

To ensure quantitative comparability of indicators characterized by different units of measurement, it is advisable to bring them to a single scale in accordance with the standardization formula (1):

$$
\mathrm{b}_{\mathrm{i}}=\frac{\mathrm{p}_{\mathrm{i}}-\mathrm{p}_{\min }}{\mathrm{p}_{\max }-\mathrm{p}_{\min }} .
$$

With this approach, indicators are assessed on the basis of meaningful ranking of the range of permissible values, theoretically ranging from 0 to 1 .

Interpretation of the levels of realization of tourist potential (I tourist flow) municipalities by threshold ranges:

$(0.67 ; 1]$ - a high level of realization of the tourist potential; 
$(0.33 ; 0.67]$ - the average level of realization of the tourist potential;

$[0 ; 0.33]-$ a low level of implementation of the tourist potential.

Interpretation of the levels of the infrastructure development indicator (I infrastructure) municipalities by threshold ranges: $(0.67 ; 1]-$ a high level of development of tourism infrastructure;

$(0.33 ; 0.67]$ - the average level of tourism infrastructure development;

$[0 ; 0.33]-$ a low level of tourism infrastructure development.

Table 1. The list of indicators of the implementation of the tourist potential and the level of infrastructure development

\begin{tabular}{|c|c|c|c|}
\hline Indicator & Indicators for Calculations & Index Calculation Method & $\begin{array}{c}\text { Indicator } \\
\text { Calculation Method }\end{array}$ \\
\hline $\begin{array}{l}\text { The level of } \\
\text { realization of } \\
\text { tourist } \\
\text { potential } \\
\quad I_{\text {tour.fl. }}\end{array}$ & $\begin{array}{l}\text { - index of attractiveness of } \\
\text { the territory according to the } \\
\text { degree of congestion of } \\
\text { collective locations ( } 1 \text { 1); } \\
-\quad \text { index of the contribution of } \\
\text { the tourism industry to the } \\
\text { economy of the municipality } \\
\text { (p2); } \\
\text { - industry productivity index } \\
\text { (p3) }\end{array}$ & $\begin{array}{l}\text { p1 = Turnover of organizations by economic } \\
\text { activities in the field of Tourism in the } \\
\text { municipality / Turnover of organizations by } \\
\text { economic activities in all industries in the } \\
\text { municipality; } \\
\text { p2 = Turnover of organizations by economic } \\
\text { activity in the tourism sector in the municipality } \\
\text { / the number of people employed in tourism in } \\
\text { the municipality. } \\
\text { p3 = The number of tourists in the municipality } \\
\text { / the population in the municipality }\end{array}$ & $\begin{array}{l}\text { Is calculated based } \\
\text { on the geometric } \\
\left.\text { mean }\left(p_{1} ; p_{2} ; p_{3}\right)\right) \\
I_{\text {tour.fl. }} \\
\quad=\sqrt[3]{\mathrm{p}_{1} * \mathrm{p}_{2} * \mathrm{p}_{3}}\end{array}$ \\
\hline $\begin{array}{l}\text { Infrastructure } \\
\text { Development } \\
\text { Indicator - } \\
\text { I Infrastructure }\end{array}$ & $\begin{array}{l}\text { - index of the provision of } \\
\text { room supply in collective } \\
\text { locations ( } 1 \text { 1); } \\
-\quad \text { index of provision of public } \\
\text { catering places ( } 2 \text { 2); } \\
-\quad \text { index of availability of tourist } \\
\text { sites (p3) }\end{array}$ & $\begin{array}{l}\mathrm{p} 1=\text { Number of rooms in collective } \\
\text { accommodations in the municipality / number } \\
\text { of tourists in the municipality; } \\
\text { p2 = Number of seats in public catering places } \\
\text { in the municipality / number of tourists in the } \\
\text { municipality; } \\
\text { p3 = Number of tourist sites in the municipality } \\
\text { / number of tourist sites in the region }\end{array}$ & $\begin{array}{l}\text { Calculated based on } \\
\text { the geometric mean } \\
\text { for each municipal } \\
\text { district: } \\
\qquad \begin{array}{l}\text { infr. } \\
\quad=\sqrt[3]{\mathrm{p}_{1} * \mathrm{p}_{2} * \mathrm{p}_{3}}\end{array}\end{array}$ \\
\hline
\end{tabular}

Source: Compiled by the authors

Diagnostics of the zones of attraction is based on the ratio of the level of realization of the tourist potential and the development of tourism infrastructure in the context of municipalities.

Based on the ratio of these indicators, the current and potential "zones of attraction" of tourists in the region are determined.

Based on the indicators of the level of implementation of the tourism potential in the field of tourism and the indicator of the development of tourism infrastructure, a positioning map of the municipal district of the region is constructed with the allocation of quadrants of the matrix according to the numerical interpretation of the indicator values.

An example of such a positioning map is shown in Figure 2.

The authors also developed a functional scheme for managing the tourism industry in the region (Figure 3).

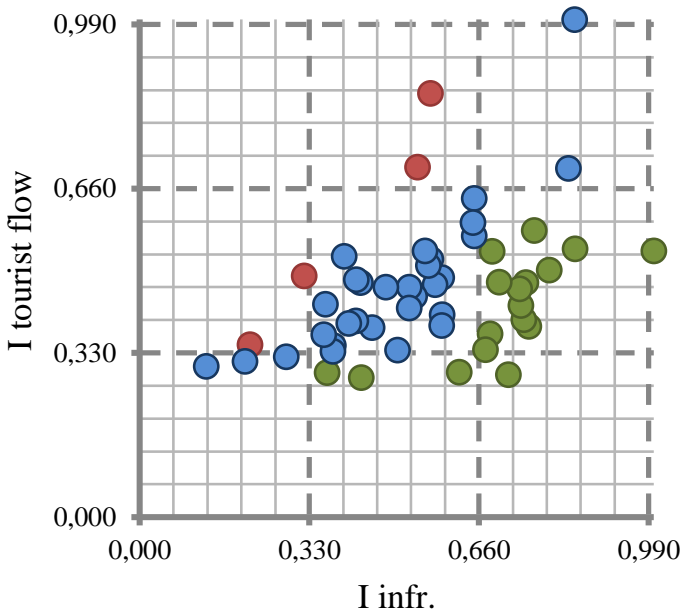

Figure 2. Positioning map of the region's municipalities in terms of the level of implementation of tourism potential and the development of tourism infrastructure

Source: Compiled by the authors 
Unified information environment for the development of the tourism industry in the region

Tourism industry monitoring Monitoring the development of tourism infrastructure

Monitoring of tourist flows Monitoring the contribution of the tourism industry to the economy Consumer portrait research
Tourism development strategy of the Russian Federation

Strategy of socio-economic development of the region

The concept of the development of the tourism industry in the region;

Tourist passports of the region and the municipality
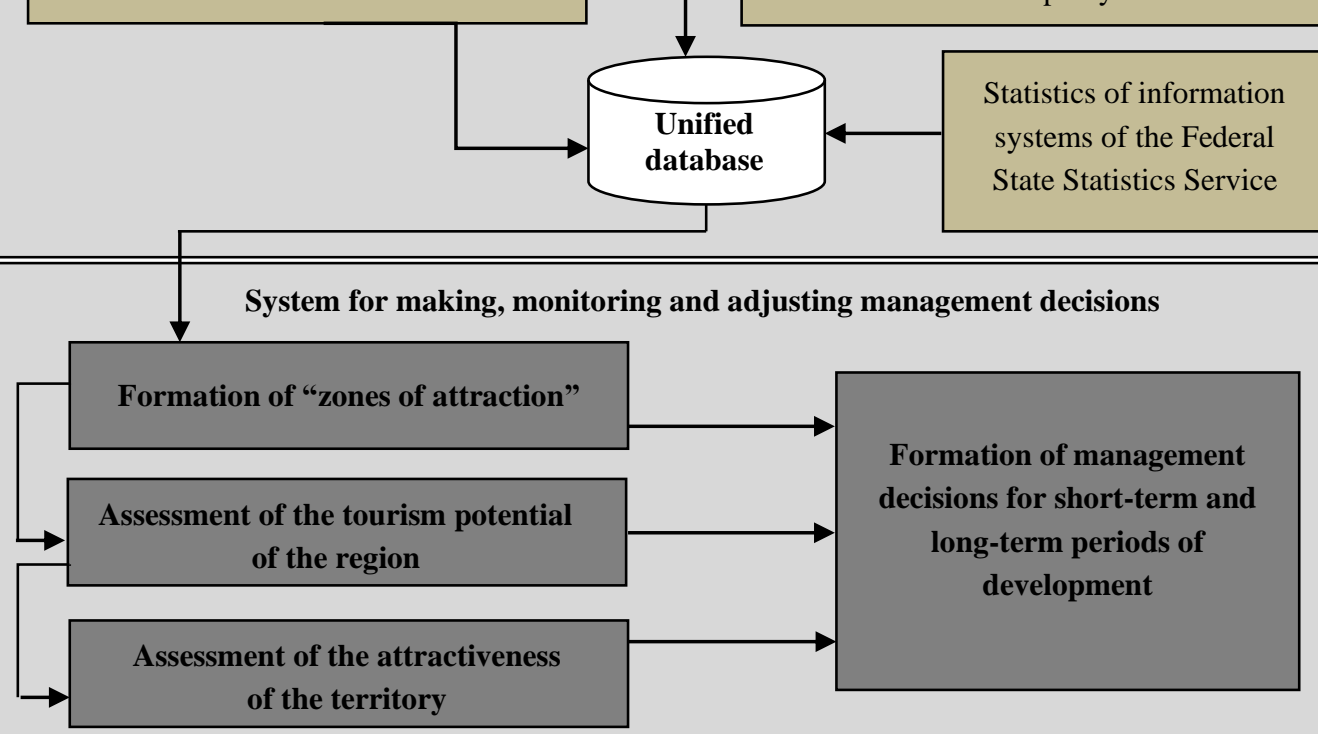

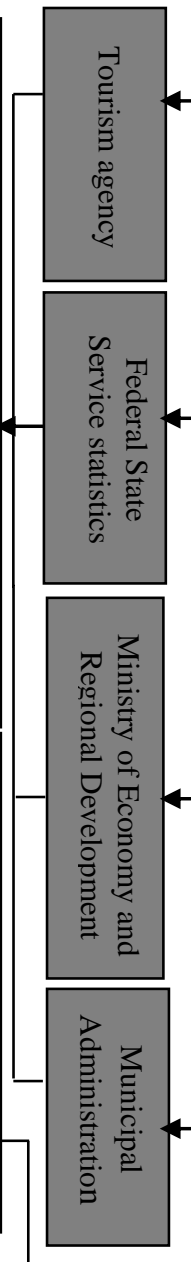

Figure 3. Functional diagram of the management of the tourism industry in the region Source: Compiled by the authors

Target tasks of the tourism industry management system in the region:

- identification of tourist attraction zones in the region;

- determination of the tourist potential of the territory and promising directions of tourism based on the information collected;

- identification of interests, preferences of tourists, drawing up a portrait of a consumer based on a survey;

- development of management solutions for the development of tourism in the region based on a comparison of the current state of the industry and consumer demands.

Tourism management functions:

- allocation of "zones of attraction" based on the assessment and analysis of criterion indicators;
- identification of key specific characteristics for "zones of attraction";

- formation of conditions for the development of domestic tourism: development of management decisions in order to increase the recognition and attractiveness of the territory;

- monitoring, control and correction of the results of management decisions: 1) formation of a common database on the current state of the industry (annual update): the number of tourists, the number of catering facilities, the number of collective accommodation facilities, etc.; 2) development of a system for an information and analytical model for monitoring the parameters of the state and development potential of the tourism industry; 3) monitoring the current state of the industry; 4) monitoring the attractiveness 
of the territory for tourists; 5) monitoring of the tourist potential of the territory.

As subjects participating in the implementation of the concept of management of the tourism industry in the region, the following were identified:

- Tourism Agency;

- Ministry of Economy and Regional Development of the Region;

- Tourism industry representatives: travel agents, tour operators;

- Representatives of the tourism industry in the municipalities of the region;
- Administration of tourist facilities;

- The population of the region and nearby subjects of the federation, considered as potential tourists.

The interaction of the subjects should be aimed at increasing the level of recognition and attractiveness of the region, the level of quality of services provided.

Securing the sphere of responsibility of the subjects of the territory according to the functions of managing the tourism industry is shown in Figure 3, Table 2 .

Table 2. The sphere of responsibility of the subjects of the tourism industry in the region

\begin{tabular}{|c|c|c|c|c|}
\hline \multirow[b]{2}{*}{ Subject of Management } & \multicolumn{4}{|c|}{ Functions } \\
\hline & 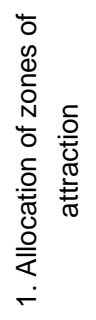 & 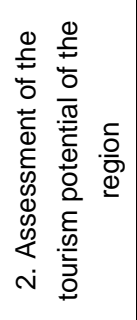 & 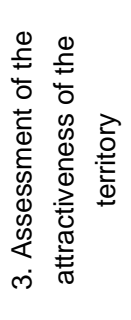 & 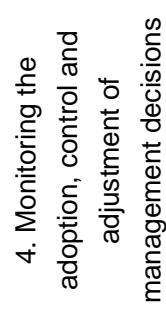 \\
\hline Tourism agency & + & + & + & + \\
\hline Representatives of the travel industry (travel agents, tour operators) & & + & + & \\
\hline Administration of the municipality in the field of tourism & + & + & + & + \\
\hline Population & & + & + & + \\
\hline Representatives of tourist sites & & + & + & + \\
\hline
\end{tabular}

Source: Compiled by the authors

Approbation of the developed concept of management of the tourism industry in the region was carried out on the example of the Krasnoyarsk Territory. Figure 4 shows the results of calculating indicators.

The group of territories with a low level of realization of the tourist potential includes 48 municipalities of the Krasnoyarsk Territory, the average share of the tourism industry contribution for them is $0.25 \%$.

The average contribution of the tourism industry to the budget of the municipalities with a high level of realization of the tourist potential is $11.8 \%$, the largest share is occupied by the Bogotolsk municipal district with a share of tourism in the economy of the district of $27.3 \%$. The share of municipalities with an average level of realization of tourist potential accounts for about $2.4 \%$ of the contribution of tourism to the development of the region.
The average rate of return from the tourism industry per employee for the group of municipal districts with a high I tourist flow was 958 thousand rubles, for the group of municipalities with an average value of the I tourist flow - 197 thousand rubles, for the group of municipal districts with a low value indicator of the first tourist flow - 146 thousand rubles.

According to the results of assessing infrastructure indicators, only the Sharypovsky district fell into the group of territories with high I infrastructure, the rest of the municipal districts were included in the group with a low level of infrastructure development. These municipal districts have an average of 64 people per place in collective accommodation facilities, 30 people per place in public catering facilities. In the Sharypovsky district, these indicators were 376 and 3454 people, respectively. 


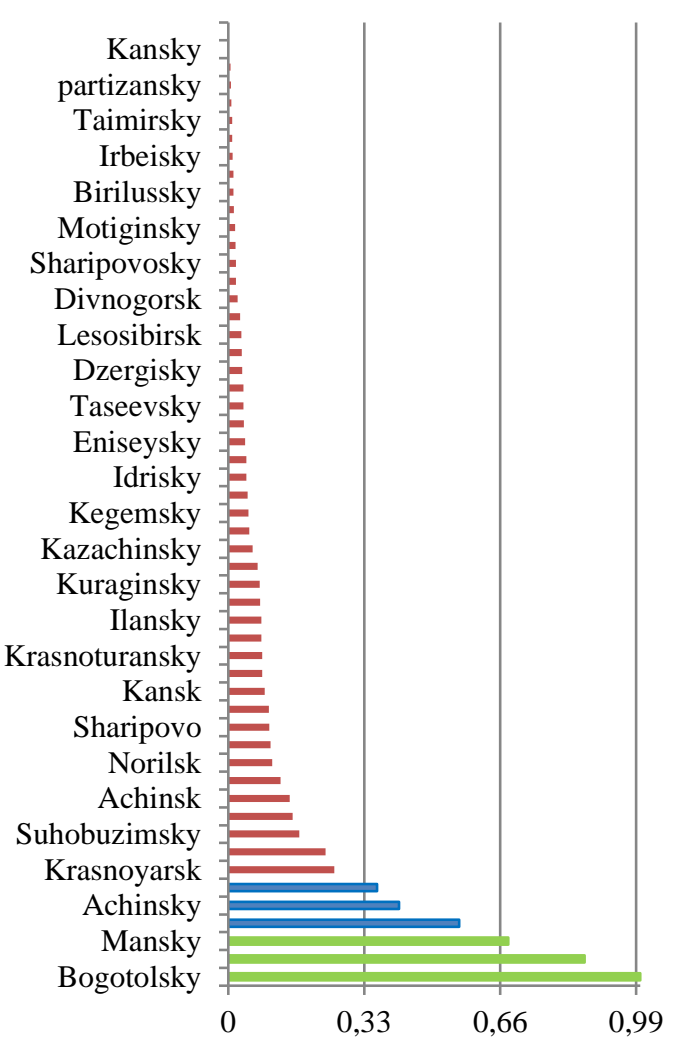

Indicator of the level of realization of tourist potential

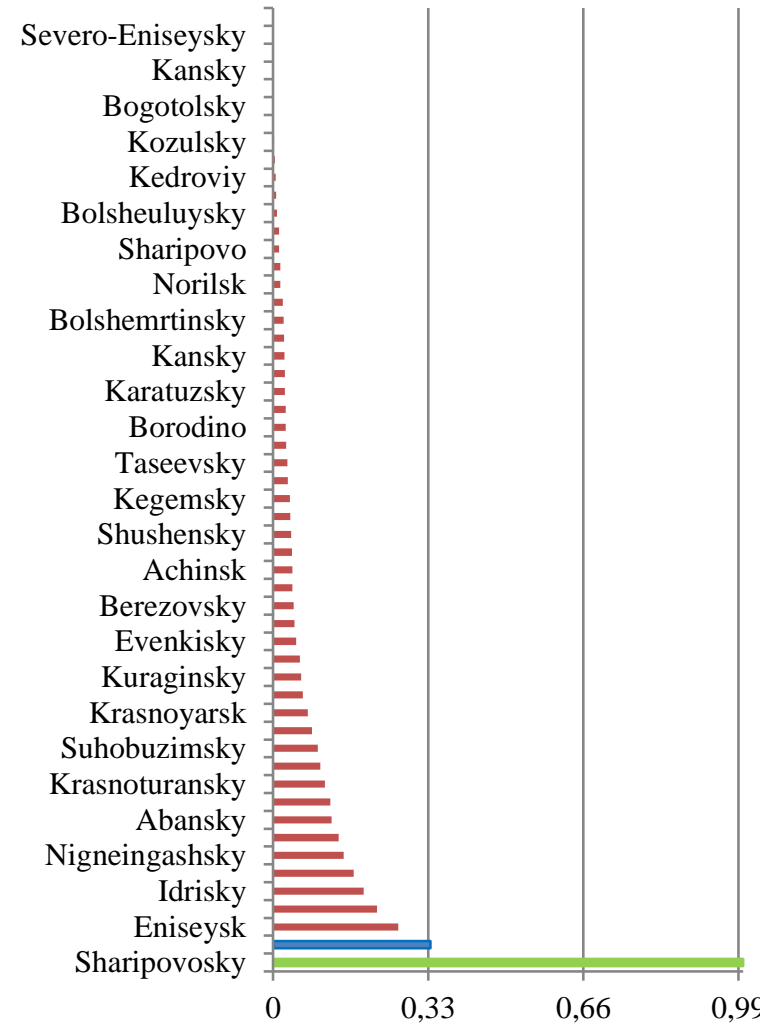

Tourism Infrastructure Development Indicator

Figure 4. The results of calculating indicators of the level of implementation of tourism potential and the development of tourism infrastructure Source: Compiled by the authors

Figure 5 shows the results of the positioning of the municipalities in terms of the level of implementation of the tourist potential and the development of tourism infrastructure.

The positioning of municipalities as a result of a pairwise combination of indicator values (I tourist flow and I infrastructure) made it possible to identify 5 territories in the Krasnoyarsk Territory with high tourist potential, which we can consider as "zones of attraction" in the region.

Also, 49 municipalities of the region with a low level of tourist potential were grouped, requiring significant development of tourism infrastructure, as well as significant investment in raising awareness, recognition and attractiveness of territories among potential clients.

Quadrants I, II of the matrix: a high level of realization of the tourist potential and a low/medium level of infrastructure development - potential "zones of attraction" for tourists. Despite the low level of development of tourism infrastructure of the territory in the areas that fall into this quadrant of the matrix, there are attractive places for tourists. It is necessary to direct investments to the development of the infrastructure of these territories and their tourist facilities and to strengthen their competitive advantages.

Quadrant III: a high level of both indicators indicates that the territories that fall into this quadrant are "zones of attraction" for tourists in the region. Concentration of resources in this segment, retention of competitive advantages, investment in the highest possible growth.

Quadrant IV: the average level of realization of tourism potential with a low level of development of tourism infrastructure. Concentration of efforts to obtain maximum results with minimum investment in infrastructure development. Investments to maintain its position in this segment.

Quadrant V: the average level of the considered indicators of I tourist flow and I infrastructure to work out options for enhancing your competitive advantages, limited methods of promoting the territory with maximum efficiency. 


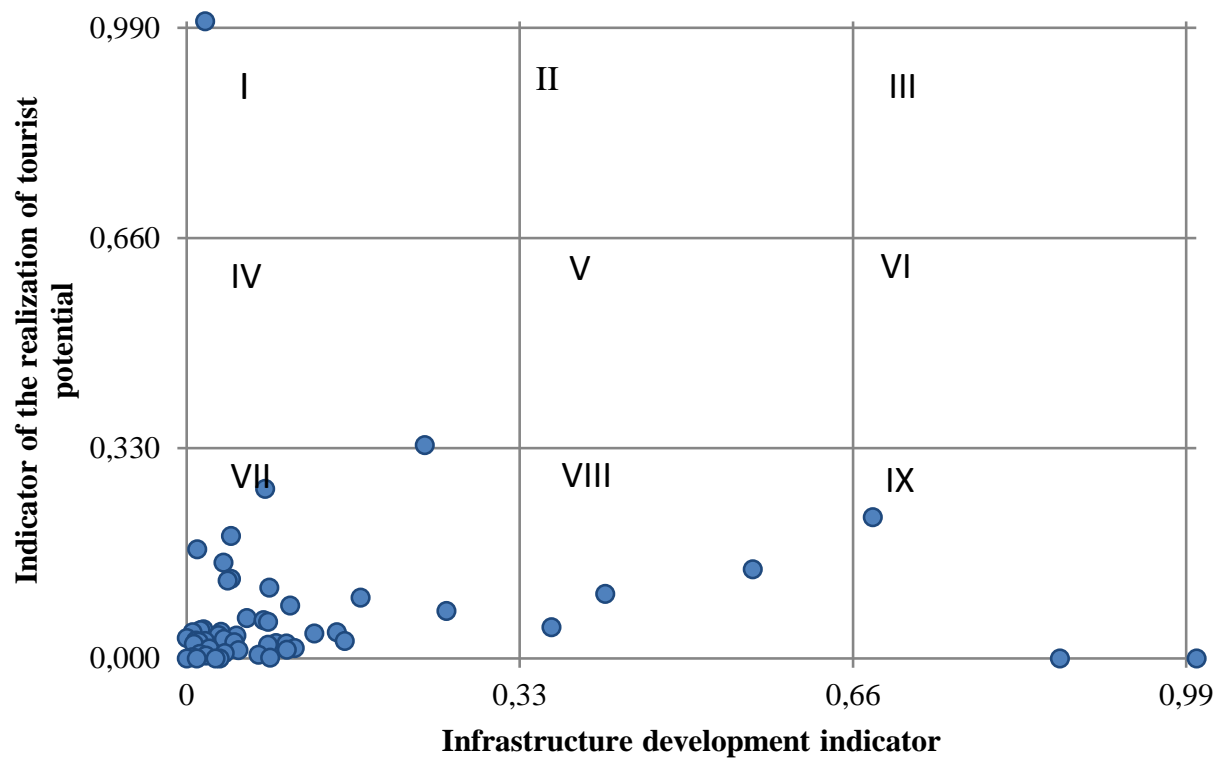

Figure 5. Positioning map of the Krasnoyarsk Territory Municipalities by the level of implementation of the tourist potential and the development of tourism infrastructure

Source: Compiled by the authors

Quadrants VI and IX. These areas include territories with high development potential potential "zones of attraction" for tourists. It is necessary to direct investments to increase awareness, recognition and attractiveness of territories among potential customers in order to strengthen their competitive advantages and strengthen their position.

Quadrant VII: low level of tourism potential realization with a low level of tourism infrastructure development. Not focusing on the tourism industry, instead focusing investments on more attractive sectors of the economy.

Quadrant VIII: low level of tourism potential realization with an average level of tourism infrastructure development. Moderate investments to achieve a rapid growth in the attractiveness of the territory, strengthening of competitive advantages for the transition to quadrant $\mathrm{V}$.

\section{DISCUSSION}

The results of this study make it possible to conduct a primary assessment of the level of development of the sphere of domestic tourism in the region.

In contrast to existing studies and developments in this topic, the analysis was carried out within the framework of the municipalities of the region, which made it possible to determine the point places of attraction of tourists and to work out in more detail possible management decisions, which together will increase the level of tourist attractiveness of the region as a whole.

\section{CONCLUSION}

In this study, the concept of managing the domestic tourism industry in the region was presented in the context of municipalities.

The results of approbation of the concept made it possible, using the example of the Krasnoyarsk Territory, to demonstrate a system for identifying current and potential "zones of attraction" of the region in the context of municipalities, which will make it possible to form management decisions in the development of the tourism industry of territories.

In further studies of this topic, it is planned to develop an automated information and analytical model for monitoring the parameters of the state and development potential of the tourism industry on the example of the Krasnoyarsk Territory.

The results obtained represent the basis for the application of the developed toolkit by the subjects of state and municipal management of the regions of Russia in order to make scientifically grounded management decisions in the development of tourism products in the region as part of the implementation of the tourism development strategy. 


\section{AUTHORS' CONTRIBUTIONS}

Anastasiya N. Rusina developed an algorithm for identifying "zones of attraction" in the region, formed a database of statistical data, on the basis of which the algorithm for identifying "zones of attraction" was tested on the example of the Krasnoyarsk Territory. Was engaged in the final approval of the version for publication. Ekaterina A. Yakimova developed a concept for the management of the tourism industry at the regional level. Was engaged in the final revision of the article and final approval of the version for publication. Olga V. Karpycheva developed a functional scheme for monitoring, controlling and adjusting management decisions. Was engaged in the final approval of the version for publication.

\section{ACKNOWLEDGMENTS}

The study was carried out with the support of the regional state autonomous institution "Krasnoyarsk Regional Fund for Support of Scientific and Scientific and Technical Activities" within the framework of the project: "Development of an information and analytical system for monitoring the state and assessing the development potential of the tourism industry in the Krasnoyarsk Territory for the preparation of strategic management decisions", application code No. 2021021007411.

\section{REFERENCES}

[1] "Strategy for the development of tourism in the Russian Federation for the period up to 2035" [Strategiya razvitiya turizma $\mathrm{v}$ Rossijskoj Federacii na period do 2035 goda] (approved by the order of the Government of the Russian Federation dated September 20, 2019, no. 2129r). (In Russ.). Retrieved from https://tourism.gov.ru/contents/documenty/strate gii/strategiya-razvitiya-turizma-v-rossiyskoyfederatsii-v-period-do-2035-goda

[2] N.K. Serdyukova, "Domestic tourism: topical issues of management and development" [Vnutrennij turizm: aktual'nye voprosy upravleniya i razvitiya], Terra Ecomomicus, 2009, vol. 7(3-3), pp.144-146. (In Russ.).

[3] D.A. Tsygankov, "Methods of analysis and planning for the development of domestic tourism in the region: at the municipal level" [Metody analiza i planirovaniya razvitiya vnutrennego turizma $\mathrm{v}$ regione: na municipal'nom urovne], Abstract of the $\mathrm{PhD}$ thesis, Moscow, 2013. (In Russ.).

[4] O. Makara, V. Maiboroda, "The current state and peculiarities of tourism management development" [Suchasniy stan ta osoblivosti rozvitku menedzhmentu turizmu], Vìsnik Marìupol's'kogo deržavnogo unìversitetu. Serîâ: Ekonomika, 2020, pp. 55-61. (In Ukr.). DOI: 10.34079/2226-2822-2020-10-20-55-61

[5] L. Andrades, F. Dimanche, "Destination competitiveness and tourism development in Russia: Issues and challenges", Tourism Management, 2017, vol. 62. pp. 360-376.

[6] I. Arbulu, M. Razumova, "Can domestic tourism relieve the COVID-19 tourist industry crisis? The case of Spain". Journal of Destination Marketing \& Management, 2021, vol. 20, p. 100568 . DOI: 10.1016/j.jdmm.2021.100568

[7] S. Khalil, M. Kakar, "Role of Tourism in Economic Growth: Empirical Evidence from Pakistan Economy", Pakistan Development Review, 2007, vol. 46(4), pp. 985-995.

[8] A. Ragab, S. Smith, S. Meis, "Domestictourism Statistics: A Comparative Analysis Of Demand Data Coverage And Method", Tourism Review International, 2020, vol. 24(1), pp. 5-21. DOI: $10.3727 / 154427220 X 15791346544752$

[9] A. Ghorbani, A. Danaei, S.M. Zargar, H. Hematian, "Designing of smart tourism organization (STO) for tourism management: A case study of tourism organizations of South Khorasan province, Iran", Heliyon, 2019, vol. 5(6), p. e01850. DOI: 10.1016/j.heliyon.2019.e01850

[10]B.E. Bayih, A. Singh, "Modeling domestic tourism: motivations, satisfaction and tourist behavioral intentions", Heliyon, 2020, vol. 6(9), p. e04839. DOI: 10.1016/j.heliyon.2020.e04839

[11]S. Gounaris, "Pursuing Alternative Demand Forecasting Approaches in the Tourism Sector", Strategic Innovative Marketing and Tourism in the COVID-19 Era, Springer, 2021, pp. 1-9. DOI: 10.1007/978-3-030-66154-0_1

[12]F.L. Chu, "Forecasting tourism demand: a cubic polynomial approach", Tourism Management, 2004, vol. 25(2), pp. 209-218. DOI: $10.1016 / \mathrm{S} 0261-5177(03) 00086-4$

[13]H. Song, G. Li, "Tourism demand modelling and forecasting - a review of recent research", 
Tourism Management, 2008, vol. 29(2), pp. 203-220.

DOI:

10.1016/j.tourman.2007.07.016

[14] N. Doğanalp. A. Arslan, "Efficiency Analysis of Tourism industry in The Southern Mediterranean Region", Social Science: Contemporary Studies in Economic and Financial Analysis, Bingley, Emerald Publishing Limited, 2021, vol. 106, pp. 49-66. DOI: $10.1108 / \mathrm{S} 1569-375920210000106004$

[15]S. Ahmeti, A. Demi, M. Katsioloudes, "The Industry of Tourism in Developing Countres: The Case of Albania", International Journal of Food and Beverage Manufacturing and Business Models, 2019, vol. 4(2), p. 18-28. DOI: 10.4018/IJFBMBM.2019070102

[16] "Tourist passport of the districts of the
Krasnoyarsk Territory" [Turistskij pasport rajonov Krasnoyarskogo kraya]. Visitsiberia.info. (In Russ.). Retrieved from https://visitsiberia.info/turpasport.html

[17] "Database of indicators of municipalities" [Baza dannyh pokazatelej municipal'nyh obrazovanij]. Federal State Statistics Service. (In Russ.). Retrieved from https://gks.ru/dbscripts/munst/munst04/DBInet. cgi

[18] "Automated information system for monitoring municipalities of the Krasnoyarsk Territory “AIS Region MO"” [Avtomatizirovannaya informacionnaya sistema monitoringa munitsipal'nykh obrazovaniy Krasnoyarskogo kraya «AIS Region MO»] (In Russ.). Retrieved from http://aismmo.econ-krsk.ru/ 